\title{
$\mathrm{X}$ 線マイクロアナライザーによるチタン窒化物 薄層皮膜の定量分析
}

\author{
三浦健一 水越朋之石神逸男 \\ 久野正人 綱沢栄二十 \\ 大阪府立産業技術総合研究所
}

J. Japan Inst. Metals, Vol. 58, No. 4 (1994), pp. 461-467

\section{Quantitative Analysis of Thin Titanium Nitride Coatings with X-ray Microanalyzer}

Ken'ichi Miura, Tomoyuki Mizukoshi, Itsuo Ishigami, Masato Kuno and Eiji Tsunasawa

Osaka Prefectural Industrial Technology Research Institute, Osaka

\begin{abstract}
Electron-probe X-ray microanalysis is convenient and practical for quantitative analysis of titanium nitride films as hard coatings. However, the conventional ZAF correction method is not applicable to thin coatings because the electron beam penetrates into a substrate. This paper concerns a quantum-theoretical analysis of thin coatings by EPMA and verification of its validity. The new analysis has been established based on the ZAF method; the analysis is given as a function of mass thickness, $\rho \times t$, where $\rho$ and $t$ are the density and the thickness of coatings respectively. Analysis of titanium nitride coatings was carried out at electron beam voltages over the range of 6 to $28 \mathrm{kV}$. For a coatings as thin as $0.54 \mu \mathrm{m}$, the chemical compositions of Ti calculated from the present analysis remained constant in the above voltage range, whereas those from the ZAF method decreased monotonically with increasing in voltage over $12 \mathrm{kV}$. On the contrary, for a thick coatings $12.55 \mu \mathrm{m}$ in thickness, the compositions obtained from both models were independent of the beam voltages. These results show that the present method is effective in the analysis of thin coatings.
\end{abstract}

(Received October 27, 1993)

Keywords: quantitative analysis, X-ray microanalyser, titanium nitride coatings, thin coatings

\section{I．緒言}

薄膜は半導体などの電子材料分野に括いてマイクロ化, 高集 積化にきわめて有効な材料として広く利用されてきた。一方, 最近では工具, 金型怙よび各種機械部品などの構造用材料分野 に括いても，主として表面機能の強化を目的とした被覆膜とし て応用されつつある.これらの構造用皮膜には付与すべき機能 に応じて種々の組成を有する合金や化合物が用いられている が，とりわけチタン窒化物皮膜は高い硬さと優れた装飾性から 現在最も研究されている皮膜の一つであり,すでにいくつかの 分野で実用化されている。

チタン窒化物は Ti-N 系状態図(1)からもわかるように, 非常 に広い組成範囲にわたって安定な化合物である。しかしその構 造, ひいては諸物性が組成に著しく依存するため(2), 正確な組 成制御が不可欠となってくる.

皮膜の組成分析には一般にXPS, AES, EPMA などが用い られている。しかしながら構造用皮膜に対して求められる機能 は, 硬さなどの機械的特性が注とんどであるため, 皮膜厚さも

†現在 : (財)関西産業公害防止センター
数 $\mu \mathrm{m}$ に及ぶのが通常である．したがって，構造用皮膜の組成 分析を行らにあたっては, 深さ方向の分析領域が通常数 $\mathrm{nm}$ と いわれるXPS やAESよりも, 通常数 $\mu \mathrm{m}$ の分析領域を持つ EPMA の方が皮膜の平均組成を把握できるという点でむしろ 適していると考觉られる.

EPMA に括ける定量分析法は, 検出される固有 $\mathrm{X}$ 線の強度 がその分析領域に剅ける重量濃度に依存するといら原理に基つ いている.これまでにZAF 法(3)を中心としていくつかの定量 補正法が提唱されてきて和り，EPMAによる定量分析は非常 に高い精度を有することで知られている。しかしながら，バル ク試料に対して確立されているこれらの補正法は，膜の分析に はそのまま啇用することができないすなおち，膜厚が薄く電 子線が膜を透過し下地基板にむで達するような場合, 得られる 情報は基板の影響を受けるため，この影響を除去しなければな らないからである.

これまでの EPMA による薄膜の定量分析法としては(1)膜が 極端に薄く, 吸収効果や蛍光励起効果が実質的に無視できる場 合にのみ適用可能な方法 (4)や, (2)膜叔よび基板中に侵入した電 子の挙動解析にモンテカルロ法を用いる方法(5)(6)などが挙げら れる. しかし，(1)は適用範囲が大きく限定されること，(2)は複 雑な解析を必要とすることなどの点で必ずしも実用的な方法と 
は言いがたい。

そこで本論文では，ZAF 法を基《構造用皮膜の定量分析に 適した定量補正法について検討するとともに，チタン窒化物皮 膜の組成分析に適用することによってその妥当性を吟味する。

\section{II. 補 正方 法}

ある化学組成をもった試料に電子線を照射すると，各元素の 固有 X 線が発生し観測される。このX 線はその発生機構から 大きく 2 種類に分けることができる.1つは電子線に上り直接 励起されることによって発生する特性 X線であり，も51つ は他の元素で発生したX線によって励起されることにより発 生する蛍光 X 線である，補正法の検討にあたり，ここではX 線発生関数を基本として各 X 線強度を計算する。

\section{1. 定量補正の基本式}

$\mathrm{A}, \mathrm{B}, \mathrm{C}, \cdots \cdots$ の元素で構成される試料から得られる $\mathrm{A}$ 元素固 有 $\mathrm{X}$ 線の強度 $I(\mathrm{~A})$ は，式(1)で表される。

$$
I(\mathrm{~A})=I(\mathrm{~A})_{\mathrm{E}}+\sum_{\mathrm{i} \neq \mathrm{A}} I(\mathrm{~A})_{\mathrm{iX}}
$$

ここで，下付き添字のEは電子線によって直接励起される $\mathrm{X}$ 線，すなわら特性 X 線のことを意味し，同じく $\mathrm{XX}$ は試料を構 成しているi元素固有 $\mathrm{X}$ 線によって励起される $\mathrm{X}$ 線，すなわ ち虽光X線を意味する、ただし， i=A，B，C，…である。

分析試料が電子線の侵入深さ上り薄い膜の場合，発生する $\mathrm{X}$ 線は膜を構成する元素の固有 $\mathrm{X}$ 線だけでなく，下地基板を 構成する $a, b, c ， \cdots \cdots$ 元素の固有 X 線む発生する。てたがっ て, 膜の構成元素である $\mathrm{A}$ 元素の固有 $\mathrm{X}$ 線強度 $I(\mathrm{~A})^{\mathrm{F}}$ は，下 地基板構成元素の固有 $\mathrm{X}$ 線に上る営光励起效果を考慮し，式 (2)で表されることとなる.

$$
I(\mathrm{~A})^{\mathrm{F}}=I(\mathrm{~A})_{\mathrm{E}}^{\mathrm{F}}+\sum_{\mathrm{i} \neq \mathrm{A}} I(\mathrm{~A})_{\mathrm{iX}}^{\mathrm{F}}+\sum_{\mathrm{i}} I^{\prime}(\mathrm{A})_{\mathrm{iX}}^{\mathrm{F}}
$$

ここで， $I^{\prime}(\mathrm{A})_{\mathrm{iX}}^{\mathrm{F}}$ は下地基板を構成する $\mathrm{i}$ 元素固有 $\mathrm{X}$ 線によっ て励起された $\mathrm{A}$ 元素の蛍光 $\mathrm{X}$ 線強度を表す $(i=a, b, c, \cdots \cdots)$. したがって，組成既知の標準試料から得られる $\mathrm{A}$ 元素の固有 $\mathrm{X}$ 線と，組成未知である薄膜試料から得られる $\mathrm{A}$ 元素固有 $\mathrm{X}$ 線の相対強度 $K_{\mathrm{A}}$ は,

$$
K_{\mathrm{A}}=\frac{I(\mathrm{~A})^{\mathrm{F}}}{I(\mathrm{~A})^{\mathrm{Std}}}=\frac{I(\mathrm{~A})_{\mathrm{E}}^{\mathrm{F}}+\sum_{\mathrm{i} \neq \mathrm{A}} I(\mathrm{~A})_{\mathrm{iX}}^{\mathrm{F}}+\sum_{\mathrm{i}} I^{\prime}(\mathrm{A})_{\mathrm{iX}}^{\mathrm{F}}}{I(\mathrm{~A})_{\mathrm{E}}^{\mathrm{Std}}+\sum_{\mathrm{i} \neq \mathrm{A}} I(\mathrm{~A})_{\mathrm{iX}}^{\mathrm{Std}}}
$$

となる、ここで，上付き添克字Std は標準試料からの固有 X

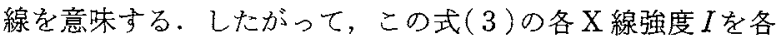
構成元素の重量濃度の関数として求めれば，実験で得られる各 元素固有 X 線の標準試料に対する相対強度 $K$ から分析試料の 各元素の重量濃度を求めることができる。

\section{2. 解析に要する諸関数および密度の決定}

以下で，式 (3) K示した各固有 $\mathrm{X}$ 線強度 $I$ 括よび密度の算 出に関して今回用いた方法について述べる。

(1) 特性 $\mathrm{X}$ 線強度 $I(\mathrm{~A}) \underset{\mathrm{E}}{\mathrm{Std}}, I(\mathrm{~A}) \frac{\mathrm{F}}{\mathrm{F}}$

標準試料の $\mathrm{A}$ 元素重量濃度を $C_{\mathrm{A}}^{\mathrm{std}}$ とすれば，深さ $\rho_{\mathrm{Std}} x$ の 領域 $\mathrm{d}\left(\rho_{\mathrm{Std}} x\right)$ で発生する $\mathrm{A}$ 元素特性 $\mathrm{X}$ 線の強度は $\mathrm{X}$ 線発生関
数 $\phi\left(\rho_{\mathrm{Std}} x\right)$ 角いて， $C_{A}^{\mathrm{Std}} \cdot \phi\left(\rho_{\mathrm{Std}} x\right) \cdot \mathrm{d}\left(\rho_{\mathrm{Std}} x\right)$ で表される。 のX線は試料表面に達するまでに試料自身伋叹されるため， 結局，観測される $\mathrm{A}$ 元素特性 X 線の強度 $I(\mathrm{~A})_{\mathrm{E}}^{\mathrm{Std}}$ は，

$$
I(\mathrm{~A})_{\mathrm{E}}^{\mathrm{Std}}=C_{\mathrm{A}}^{\mathrm{Std}} \cdot \int_{0}^{\infty} \phi\left(\rho_{\mathrm{Std}} x\right) \cdot \exp \left(-\chi_{\mathrm{A}}^{\mathrm{Std}} \cdot \rho_{\mathrm{Std}} x\right) \cdot \mathrm{d}\left(\rho_{\mathrm{Std}} x\right)
$$

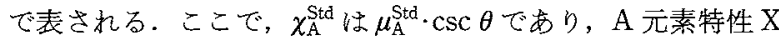
線住対する標準試料の質量吸収係数をX線取り出し角の正弦 で除したものである。また， $\rho_{\mathrm{Std}}$ は標準試料の密度，xは表面 からの深さを表す。

薄膜試料の場合も同様であり，A元素の存在する範用が表 面から深さ $t$ ，すなわち膜厚までであるので， $I(\mathrm{~A})$ 舀は，

$$
I(\mathrm{~A})_{\mathrm{E}}^{\mathrm{F}}=C_{\mathrm{A}} \cdot \int_{0}^{\rho_{\mathrm{F}} t} \phi\left(\rho_{\mathrm{F}} x\right) \cdot \exp \left(-\chi_{\mathrm{A}}^{\mathrm{F}} \cdot \rho_{\mathrm{F}} x\right) \cdot \mathrm{d}\left(\rho_{\mathrm{F}} x\right)
$$

となる。ここに $\rho_{\mathrm{F}}$ は薄膜の密度, $\chi_{\mathrm{A}}^{\mathrm{F}}$ はA 元素特性 X 線に対 する薄膜の質量吸収係数をX 線取り出し角の正弦で除したも のである。

（2）他元素の固有 $\mathbf{X}$ 線により蛍光励起された $\mathbf{X}$ 線強度 $I(\mathrm{~A})_{\mathrm{iX}}^{\mathrm{Std}}, I(\mathrm{~A})_{\mathrm{iX}}^{\mathrm{F}}$

蛍光 $\mathrm{X}$ 線中には他の特珄 $\mathrm{X}$ 線により蛍光励起されるものと 連続 X 線によって励起されるものがある，連続X線による蛍 光励起は未知試料，標染試料でともに起こる現象であるので， $\mathrm{X}$ 線相対強度を算出する際に互いに相殺するように㗢き，こ の効果は汪とんど無視できる。しかしながら，他の特性 X 線 による蛍光励起は，複数の元素で構成された試料でのみ起こる 現象であるため，未知試料と標準試料とでその効果は大きく異 なることがある。ここでは他元素特性 X 線による蛍光励起分 を薄膜部，基板部の両方について求める.

他元素の特性 X 線による営光励起 X 線の発生は, 艺の X 線 が試料に吸收されることに起因する。したがって，各元素の特 性 X 線による蛍光励起分の強度は，之の特性 X 線の吸収量に 励起効率を掛けることで求めることができる。いま，標準試料 の深さ $\rho_{\mathrm{Std}} x て ゙ の$ 領域 $\mathrm{d}\left(\rho_{\mathrm{Std}} x\right)$ で発生する $\mathrm{i}$ 元素の特性 $\mathrm{X}$ 線強 度を考克る。它の強度は $\mathrm{X}$ 線発生関数 $\phi\left(\rho_{\mathrm{Std}} x\right)$ を用いて $C_{\mathrm{i}}^{\mathrm{Stc}}$. $\phi\left(\rho_{\mathrm{Sta}} x\right) \cdot \mathrm{d}\left(\rho_{\mathrm{Std}} x\right)$ で表される。このX線が表面到達までに表 面から深さ $\rho_{\mathrm{Std}} y$ の領域 $\mathrm{d}\left(\rho_{\mathrm{Std}} y\right)$ で吸収される量 $I_{\mathrm{i}}$ は,

$$
\begin{aligned}
I_{\mathrm{i}}= & C_{\mathrm{i}}^{\mathrm{Std}} \cdot \phi\left(\rho_{\mathrm{Std}} x\right) \cdot \chi_{\mathrm{i}}^{\mathrm{Std}} \cdot \exp \left\{-\chi_{\mathrm{i}}^{\mathrm{Std}} \cdot\left(\rho_{\mathrm{Std}} x-\rho_{\mathrm{Sta}} y\right)\right\} \cdot \mathrm{d}\left(\rho_{\mathrm{Std}} y\right) \\
& \times \mathrm{d}\left(\rho_{\mathrm{Std}} x\right)
\end{aligned}
$$

で表すことができる、この吸收量のうちA元素によって吸収 される量は,

$$
C_{\mathrm{A}}^{\mathrm{Sta}} \cdot \frac{\chi_{\mathrm{i}}^{\mathrm{A}}}{\chi_{\mathrm{i}}^{\mathrm{std}}} \cdot I_{\mathrm{i}}
$$

で表される。よって，式（７）にA 元素 $\mathrm{K}$ 殼をイオン化する割 合 $\left(r_{\mathrm{A}}-1\right) / r_{\mathrm{A}}$ と虽光収率 $\omega_{\mathrm{K}}\left(Z_{\mathrm{A}}\right)$ を掛政的ば，表面から距離 $\rho_{\mathrm{Std}} x$ の領域 $\mathrm{d}\left(\rho_{\mathrm{Std}} x\right)$ で発生したi 元素特性 $\mathrm{X}$ 線によって, 表 面から距離 $\rho_{\mathrm{Sta}} y$ の領域 $d\left(\rho_{\mathrm{Std}} y\right)$ で営光励起される $\mathrm{A}$ 元素絈光 $\mathrm{X}$ 線の強度 $I_{\mathrm{A}}$ 求めることができる。すなわち，

$$
I_{\mathrm{A}}=C_{\mathrm{A}}^{\mathrm{Std}} \cdot \frac{\chi_{\mathrm{i}}^{\mathrm{A}}}{\chi_{\mathrm{i}}^{\mathrm{Std}}} \cdot \frac{r_{\mathrm{A}}-1}{r_{\mathrm{A}}} \cdot \omega_{\mathrm{K}}\left(Z_{\mathrm{A}}\right) \cdot I_{\mathrm{I}}
$$

となる.この虽光励起された A 元素虽光 X 線は, 距離 $y$ を経 て表面から脱出するため自己吸収を受ける．このことを考慮す れば， $\mathrm{i}$ 元素特性 $\mathrm{X}$ 線比よって虽光励起された $\mathrm{A}$ 元素蛍光 $\mathrm{X}$ 線の強度 $I(\mathrm{~A})_{\mathrm{iX}}^{\mathrm{Std}}$ は, 


$$
\begin{aligned}
I(\mathrm{~A})_{\mathrm{iX}}^{\mathrm{Std}}= & C_{\mathrm{A}}^{\mathrm{Std}} \cdot C_{\mathrm{i}}^{\mathrm{Std}} \cdot \chi_{i}^{\mathrm{A}} \cdot \frac{r_{\mathrm{A}}-1}{r_{\mathrm{A}}} \cdot \omega_{\mathrm{K}}\left(Z_{\mathrm{A}}\right) \cdot \int_{0}^{\infty} \int_{0}^{\rho_{\mathrm{Sdd} t}} \phi\left(\rho_{\mathrm{Std}} x\right) \\
& \times \exp \left(-\chi_{\mathrm{A}}^{\mathrm{Std}} \cdot \rho_{\mathrm{Std}} y\right) \cdot \exp \left\{-\chi_{\mathrm{i}}^{\mathrm{std}} \cdot\left(\rho_{\mathrm{Std}} x-\rho_{\mathrm{Std}} y\right)\right\} \\
& \times \mathrm{d}\left(\rho_{\mathrm{Std}} y\right) \cdot \mathrm{d}\left(\rho_{\mathrm{Std}} x\right)
\end{aligned}
$$

となる。試料が薄膜の場合は当然,

$$
\begin{aligned}
I(\mathrm{~A})_{\mathrm{iX}}^{\mathrm{R}}= & C_{\mathrm{A}} \cdot C_{\mathrm{i}} \cdot \chi_{\mathrm{i}}^{\mathrm{A}} \cdot \frac{\gamma_{\mathrm{A}}-1}{r_{\mathrm{A}}} \cdot \omega_{\mathrm{K}}\left(Z_{\mathrm{A}}\right) \cdot \int_{0}^{\rho_{\mathrm{F}} t} \int_{0}^{\rho_{\mathrm{F}} x} \phi\left(\rho_{\mathrm{F}} x\right) \\
& \times \exp \left(-\chi_{\mathrm{A}}^{\mathrm{F}} \cdot \rho_{\mathrm{F}} y\right) \cdot \exp \left\{-\chi_{\mathrm{i}}^{\mathrm{F}} \cdot\left(\rho_{\mathrm{F}} x-\rho_{\mathrm{F}} y\right)\right\} \\
& \times \mathrm{d}\left(\rho_{\mathrm{F}} y\right) \cdot \mathrm{d}\left(\rho_{\mathrm{F}} x\right)
\end{aligned}
$$

である。

（3）下地基板からの固有 $\mathrm{X}$ 線により举光励起された $\mathrm{X}$ 線強 度 $I^{\prime}(\mathbf{A})_{\mathrm{iX}}^{\mathrm{F}}$

まず，下地で発生する $\mathrm{i}$ 元素の固有 $\mathrm{X}$ 線の膜之基板の界面 到達時の強度 $I(\mathrm{i})$ Sub 飞ついて考光る。基板が多元素から構成 されている場合㴗当然,

$$
I(\mathrm{i})^{\mathrm{Sab}}=I(\mathrm{i})_{\mathrm{E}}^{\mathrm{Sub}}+\sum_{\mathrm{j} \neq \mathrm{i}} I(\mathrm{i})_{\mathrm{jX}}^{\mathrm{Sub}}
$$

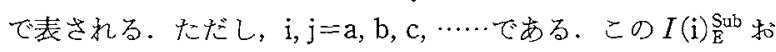
よび $I(\mathrm{i})_{\mathrm{j} \mathrm{X}}^{\mathrm{Sub}}$ は，下地基板での $\mathrm{X}$ 線発生関数 $\phi_{\mathrm{S}}\left(\rho_{\mathrm{Sub}} x\right)$ を用い れば，式(4)，(9)と同様に求めることができる、すなわら，

$$
\begin{aligned}
I(\mathrm{i}) \underset{\mathrm{E}}{\mathrm{Sub}}= & C_{\mathrm{i}}^{\mathrm{Sub}} \cdot \int_{0}^{\infty} \phi_{\mathrm{S}}\left(\rho_{\mathrm{Sub}} x\right) \cdot \exp \left(-\chi_{\mathrm{i}}^{\mathrm{Sub}} \cdot \rho_{\mathrm{Sub}} x\right) \cdot \mathrm{d}\left(\rho_{\mathrm{Sub}} x\right) \\
I(\mathrm{i})_{\mathrm{j} X}^{\mathrm{Sub}}= & C_{\mathrm{i}}^{\mathrm{Sub}} \cdot C_{\mathrm{j}}^{\mathrm{Sub}} \cdot \chi_{\mathrm{j}}^{\mathrm{i}} \cdot \frac{r_{\mathrm{i}}-1}{r_{\mathrm{i}}} \cdot \omega_{\mathrm{K}}\left(Z_{\mathrm{i}}\right) \cdot \int_{0}^{\infty} \int_{0}^{\rho_{\mathrm{Suw}} x} \phi_{\mathrm{S}}\left(\rho_{\mathrm{Sub}} x\right) \\
& \times \exp \left(-\chi_{\mathrm{i}}^{\mathrm{Sub}} \cdot \rho_{\mathrm{Sub}} y\right) \cdot \exp \left\{-\chi_{\mathrm{j}}^{\mathrm{Sub}} \cdot\left(\rho_{\mathrm{Sub}} x-\rho_{\mathrm{Sub}} y\right)\right\} \\
& \times \mathrm{d}\left(\rho_{\mathrm{Sub}} y\right) \cdot \mathrm{d}\left(\rho_{\mathrm{Sub}} x\right)
\end{aligned}
$$

が得られる、ただし，式(12)，(13)は原点を膜と基板の界面比 とってある. したがって，このI(i) Sub を用い机ば式(10)尊出 と同様の方法で，下地基板で発生した固有 X線に上る薄膜構 成元素の営光励起分を求めることができる.かくして，

$$
\begin{aligned}
I^{\prime}(\mathrm{A})_{\mathrm{iX}}^{\mathrm{F}}= & C_{\mathrm{A}} \cdot \frac{r_{\mathrm{A}}-1}{r_{\mathrm{A}}} \cdot \omega_{\mathrm{K}}\left(Z_{\mathrm{A}}\right) \cdot \frac{\chi_{\mathrm{i}}^{\mathrm{A}}}{\chi_{\mathrm{i}}^{\mathrm{F}}-\chi_{\mathrm{A}}^{\mathrm{F}}} \cdot\left\{\exp \left(-\chi_{\mathrm{A}}^{\mathrm{F}} \cdot \rho_{\mathrm{F}} t\right)\right. \\
& \left.-\exp \left(-\chi_{\mathrm{i}}^{\mathrm{F}} \cdot \rho_{\mathrm{F}} t\right)\right\} \cdot I(\mathrm{i})^{\mathrm{Sub}}
\end{aligned}
$$

が得られる。

\section{(4) 皮膜の密度}

上記の補正計算を実行するためには，度膜を構成している各

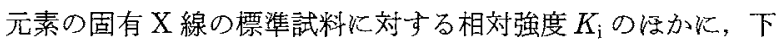
地基板構成元素の濃度 $C_{1}^{\mathrm{Sub}}$ および $\rho_{\mathrm{F}} t$ ，すなわら皮膜密度と膜 愿が必要となる，基板の組成が不明である場合は少ないと考克 られるが，皮膜の密度や膜厚は実際に測定しない限り不明であ ることが多い，特に膜の密度については，合金膜のような場合 には, 便宜上, 各構成元素の単体での密度を各構成元素濃度か ら荷重平坮的炕求めるといら方法がとられているが，化合物皮

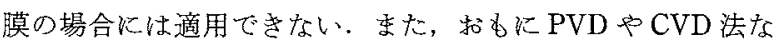
どにより成膜されるチタン窒化物皮膜では，成膜時の制御パラ メータにより膜の密度がそのバルクでの密度からずれるといら ことが知られて括り (7)，膜厚と同様に試料每の值が必要とな る. 膜厚は試料断面の SEM 観察などにより比較的容易に湘定 することができるが，膜の密度の測定は容易ではなく，特に膜 厚が薄くなる汪ど測定が困難になると考克られる．今回の分析 では, 補正計算の過程に括いて下地基板からの固有 $\mathrm{X}$ 線強度
の標準試料に対する相対強度から $\rho_{\mathrm{F}} t$ を算出するという方法を とった。すなわち，膜の $\rho_{\mathrm{F}} t$ は式(11)より観測されるi元素の 固有 X 線の強度を $I_{\mathrm{m}}(\mathrm{i})$ Sub とすれば， $\mathrm{i}$ 元素の標準試料との $\mathrm{X}$ 楾相対強度を $K_{\mathrm{i}}$ として式(15)で表される.

$$
\rho_{\mathrm{F}} t=\frac{1}{\chi_{\mathrm{i}}^{\mathrm{F}}} \cdot \ln \left(K_{\mathrm{i}} \cdot \frac{I_{\mathrm{m}}(\mathrm{i})^{\mathrm{Sub}}}{I(\mathrm{i})^{\mathrm{Std}}}\right)
$$

\section{III. 補正法の妥当性に対する検証}

\section{1. 分析方法}

\section{(1) 分析試料}

分析に供した試料はHCD 万式のイオンプレーティング装置 (㑣昭和真空製)を用いて作製したチタン窒化物皮膜である．基 板は高速度工具鋼 SKH-51 で真空熱処理後ラッピング仕上げ したものを用いた。基板材料の化学組成を Table 1 亿示す. 前処理として, アセトン中での超音波洗浄で脱脂し, さらに被

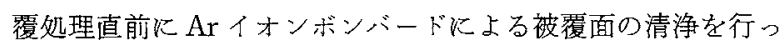
た。皮膜厚さは試料抣断面を研磨し走查型電子顕微鏡 (SEM) により測定した。各試料の膜厚を Table 2 に示す。

\section{(2) 分析条件}

EPMA 比よる分析恃日本電子(特製 JXA-733 形 X 線マイク ロアナライザーを用いた。標準試料として Ti(日本電子データ 么(休販売)，VN(日本新金属制，ホットプレス； $2273 \mathrm{~K}, 98$ $\mathrm{MPa}, 7.2 \mathrm{ks}$ )， $\mathrm{Fe}$ (日本電子データム侏販売) 3 種を用意した. それぞれの純度を Table 2 に示す。電子線のプローブ径は 10 $\mu \mathrm{m}$ とした。定量補正計算に用いる固有 $\mathrm{X}$ 線はすべて $\mathrm{K} \alpha$ 線 る採用した．分光結晶は $\mathrm{TiK} \alpha$ 線拉よび $\mathrm{FeK} \alpha$ 線については $\mathrm{PET}$ を $\mathrm{NK} \alpha$ 線についてはSTEを用いた。京た，各 $\mathrm{X}$ 線の

\begin{tabular}{|c|c|c|}
\hline \multirow{2}{*}{ Sample } & A & Thickness $12.55 \mu \mathrm{m}$ \\
\hline & B & Thickness $0.54 \mu \mathrm{m}$ \\
\hline \multirow{3}{*}{$\begin{array}{l}\text { Standard } \\
\text { sample }\end{array}$} & $\overline{\mathrm{Ti}}$ & 99.9 mass $\%$ \\
\hline & VN & 99.11 mass $\%$ (V: 81.58 mass\% $\quad$ N: 17.53 mass\%) \\
\hline & $\mathrm{Fe}$ & 99.99 mass $\%$ \\
\hline
\end{tabular}
強度は， $\mathrm{NK} \alpha$ 線が軽元素の固有 X 線であることから，化合状 態の違いKよるX線スペクトルの形状変化などによるピーク 強度変化の影響炎避けるため，すべて面積強度とした ${ }^{(8)}$ ，各固 有 $\mathrm{X}$ 線のスペクトルはパーソナルコンピューターにより自動 計測可能なシステムにより測定される。それぞれの試料から得 られた TiK $\alpha$ 線， NK $\alpha$ 線，执よび $\mathrm{FeK} \alpha$ 線の相対強度を用い て，上記の補正計算により定量值を算出した。 また，求めた定 量值は原子\%に変換し規格化して皮膜組成値とした。

Table 1 Chemical composition of SKH-51 substrate used (mass \%).

\begin{tabular}{c|c|c|c|c|c|c|c}
\hline \hline $\mathrm{C}$ & $\mathrm{Si}$ & $\mathrm{Mn}$ & $\mathrm{Cr}$ & $\mathrm{Mo}$ & $\mathrm{V}$ & $\mathrm{Co}$ & $\mathrm{W}$ \\
\hline 0.89 & 0.27 & 0.27 & 3.98 & 4.80 & 1.96 & 0.40 & 6.15 \\
\hline
\end{tabular}

Table 2 Thickness of TiN films and purity of standard samples prepared for this experiment. 


\section{(3) TiLl 線亡 NK $\alpha$ 線の分離}

EPMA でチタン窒化物系化合物の分析を行ら場合， NK $\alpha$ 線 とTiLI 線が重畳する現象が起こる，双方ともに一次回折線で あるため，波高分析機などによる分離もできないことから定量 值算出に用いる $\mathrm{NK} \alpha$ 線の強度は直接測定できない。

$\mathrm{NK} \alpha$ 線と TiLl 線の分離方法についてはこれまでいくつかの 方法が提案されている。(1)標準試料で岁るTiから得られた $\mathrm{TiK} \alpha$ 線と, Ti-N 系分析試料から得られた TiK $\alpha$ 線との相対 強度が，それぞれから得られる TiLI 線の相対強度と等しいと 近似して，分析試料から得られるでする $\mathrm{TiLl}$ 線の強度を算 出する方法 ${ }^{(8)}$ や，(2) ZAF 法を応用して理論的に TiLl線の強 度を算出するという方法 ${ }^{(9)}$, さらに, (3) NK $\alpha$ 線之TiLl 線の スペクトルを直接測定できる試料に和いて測定し，その2つ のスペクトル波形を用いて分析試料から得られる重囸波形を分 離するといら方法(10)などがある。

これらの方法のらら(1)の方法は，標準試料と分析試料での各 固有 X線に対する質量吸収係数の違いについて全く考慮され ないため，かなり近似的な方法であるといえる。また，(2)の方 法は分析試料の Ti の組成比を直接観測が可能な TiK $\alpha$ 線の相 対強度で近似し，残りをNの組成比として，この組成比から 理論的に TiLl 線の強度を算出するといらあのであるが，この 万法の場合，バルク試料に対しては適用可能であるが，合回我 々が目的とする膜厚の薄い試料に対しては，そのまま適用する ことができない，

今回の分析では，X 線発生領域执よび下地基板の影響に対 して低存度が少ないと考光られる(3)の方法をとった。標準波形 としては，Tiから得られる TiLl 線とVNから得られる NKa 線を採用した. Fig. 1 亿加速電厈 $10 \mathrm{kV}$ で測定した TiL1 線之 $\mathrm{NK} \alpha$ 線標集波形と試料 B か 畳波形を示す，NK $\alpha$ 線の標準波形については，先にす述べた が，㪕元素の固有 X 線であることから，その化合状態による スペクトルの形状変化などの現象を考慮し，化合状態が Ti-N 系化合物之比較的近いと考光られるVNを用いた。分析試料 から得られる重畳波形を，この 2 つ標準波形を用いて最小 二乗法に上り分離し， $\mathrm{NK} \alpha$ 線強度を求めた。

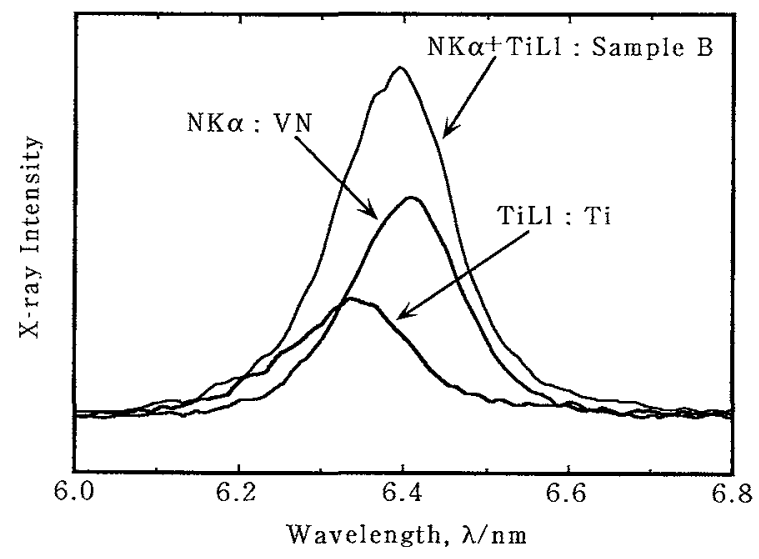

Fig. 1 Spectra of $\mathrm{NK} \alpha$ from VN and TiLI from Ti used for separation of spectra of $\mathrm{NK} \alpha$ and TiLl from TiN; electron beam voltage, $10 \mathrm{kV}$.

\section{2. 具体的な補正計算法}

補正計算を実行するためには，等ずX線発生関数を定義す る必要がある。このX 線発生関数についてはPhilibert $の \mathrm{X}$ 線発生関数を用いた．Philibert のX 線発生関数は式(16)で表 される。

$\phi(\rho x)=R_{\infty} \cdot \omega_{\mathrm{K}}\left(Z_{\mathrm{A}}\right) \cdot \frac{N_{0}}{A_{\mathrm{A}}} \cdot \psi_{\mathrm{A}} \cdot\left[\exp (-\sigma \cdot \rho x)-\left(1-R_{0} / R_{\infty}\right)\right.$

$$
\times \exp \{-(\sigma+k) \cdot \rho x\}]
$$

ここに, $R_{0}$ 愔試料表面近くの平均 Electron Path, $R_{\infty}$ は完全 拡散点に和ける平均Electron Path, $N_{0}$ はアボガド口数， $\phi_{\mathrm{A}}$ はイオン化断面積，のはレナード定数である。京た $k$ は次式で 与克らる。.

$$
k=\text { Const } \cdot \frac{Z_{\mathrm{A}}^{2}}{A_{\mathrm{A}}} \cdot \frac{1}{E_{0}}
$$

当然のことながら，X線発生関数には試料中での電子の散乱 や各元素のイオン化断面積などについて含まれていなければな らないここのX 線発生関数は，ZAF 法の吸收効果係数算出の 際に用いられるものであるが，あらためて原子番号効果 $(Z) に$ ついて計算しなければならないことからも分かるように，ほと えどそれらの效果について含委れていないことは周知の通りで ある.このことについては, 実験結果も踏まえて議論すること 飞する。な括，下地基板での基板構成元素の特性 X 線発生関 数 $\phi_{\mathrm{S}}\left(\rho_{\mathrm{Sub}} x\right)$ は, Philibert $の \mathrm{X}$ 線発生関数の形から考光て, 式(18)の上らに表されることは明らかである。

$$
\phi_{\mathrm{S}}\left(\rho_{\mathrm{Sub}} x\right)=\phi\left(\rho_{\mathrm{Sub}} x+\rho_{\mathrm{F}} t\right)
$$

補正計算式は, 未知の濃度と密度の関数で与兄られている。 したがって，計算手法としては，分析により得られた各元素の 固有 $\mathrm{X}$ 線の相対強度 $K$ をとれらの重量濃度と近似(第一次近 似)して計算し, 得られた各元素の重量濃度を用いて, 再度同 様の計算を行い(第二次近似)，この操作を得られる重量濃度が 収束するまで繰り返すという，従来のZAF 法でとられている 逐次近似法を用いた。密度について子同様の計算を行ったが， 第一次近似としては適当な数值を代入した。

\section{3. 検証結果および考察}

本補正計算の妥当性を議論するため, 様々な加速電圧で份析 を行い, 補正後に得られる定量值の加速電圧低存性について調 べた。すなわら，薄膜試料に齐して故意にその深さ力向の分析 領域を変化させ，その定量值の変化を調べることで，本補正計 算の膜厚が薄い試料に対する妥当性についての議論が可能とな ると考兑る。

Fig. 2 に試料 Bから得られた FeK $\alpha$ 線の標準試料 Fe に対 する相対強度の加速電圧による变化を示す. 加速電圧 $10 \mathrm{kV}$ に执いても確実に下地基板からのるの思われる $\mathrm{FeK} \alpha$ 線が 観測され，明らかに皮膜部分を電子線が透過していることがわ かる、な颃，試料 AKついても同様の分析を行ったが，加速 電圧が $28 \mathrm{kV}$ に和いて子 $\mathrm{FeK} \alpha$ 線は错測されなかった。これ により，試料 AKついては通常の ZAF 法の適用が可能である と考支られるが，試料 B の場合は明らかにX 線発生領域就よ び下地基板からのX 線の影響を考慮しなければならないとい らことがわかる。 


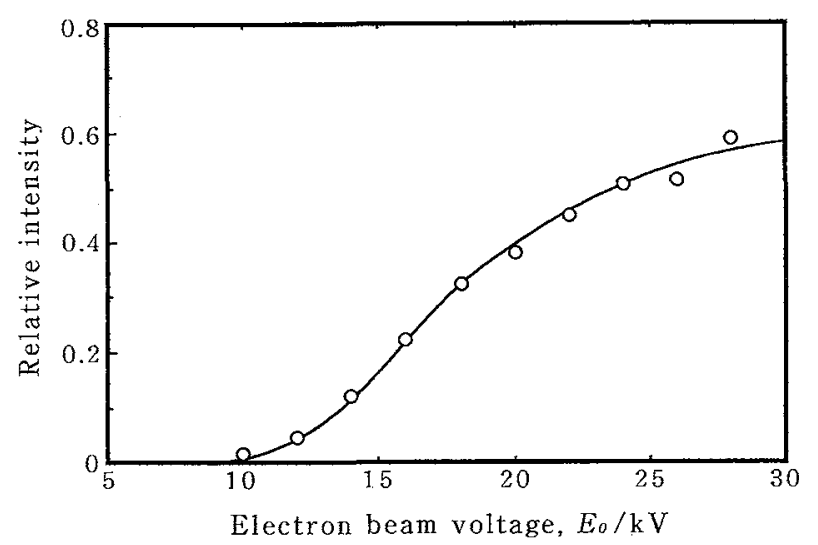

Fig. 2 A change in intensity of $\mathrm{FeK} \alpha$ from sample $\mathrm{B}$ with electron beam voltage. The intensity is represented by comparison with that of $\mathrm{FeK} \alpha$ obtained from a standard sample of Fe. Sample B consists of a thin film $0.54 \mu \mathrm{m}$ thick deposited onto a SKH-51 substrate; hence, the electron beam penetrates into the substrate.

\section{（1）厚膜に対する従来法と本法の比較}

試料A についての分析結果をFig. 3 亿示す. Fig. 3 には上 記の補正計算による結果と $\mathrm{ZAF}$ 法による結果とを同時に示し た. 当然のことながら，どのような加速電圧で分析しようとも 得られる定量值は一定でなければならない.どららの補正計算 に上る結果も，分析值に多少のばらつきはるるのの，加速電

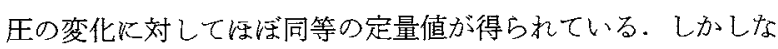
がら，上記の補正計算による分析結果はZAF 法による結果を ちょらど高濃度側にシフトした形となっている。バルク試料に 対してのZAF 法による分析精度がかなり高いといら立場で比 較すれば，上記の補正計算による分析結果は定量精度の面であ まり良いものとはい完ないいらことになる。これは先にる述 ベたように Philibert のX線発生関数を用いているためであ り，原子番号効果が汪とんど加味されていないことが原因であ る、に多かかわらず得られた組成值が加速電在に対してあまり 依存しない結果となっているのは，今回分析火供した分析試料

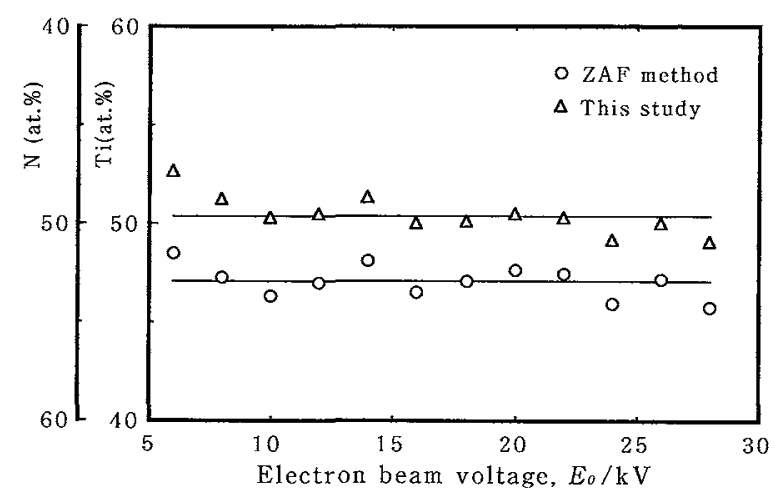

Fig. 3 A comparison of chemical composition of sample A determined by the conventional ZAF method and by this method. For sample A, TiN film is very thick, being 12.55 $\mu \mathrm{m}$ in thickness; therefore, electron beam does not reach the substrate.
と標準試料の組合せでは原子番号効果補正俰数が加速電圧に対 してあまり変化しないためと考穴られる。試料 A は今回の分 析での加速電圧の範囲においては， $\mathrm{FeK} \alpha$ 線が篗測されなかっ たことから考光てバルク試料であるといって良い，上記の補正 計算に蛇いては膜の密度を算出することができないため, 膜の 密度をTiNのバルクの密度である $5.44 \times 10^{3} \mathrm{~kg} / \mathrm{m}^{3(11)}$ として 補正計算を行った。この補正計算では， $\rho_{\mathrm{F}} t$ に対してのを代入 したものと同様であるため，計算自体はZAF 法における吸収 効果係数の算出と何ら变わりの無いものとなる. しかしながら, ZAF 法ではこのX線発生強度に効して, 式 (4)のラプラス変 換により得られた関数 $F(\chi)$ K=0を代入して得られた值で 除して規格化することで，分析試料と標準試料との間での自己 吸収の違いのみ補正し，各試料の平均原子番号の違い炕つい ての補正は改めて行うといら方法がとられている。したがっ て, 試料 A の場合, 上記の補正計算に秃いて ZAF 法と同様に $\mathrm{X}$ 線発生強度を規格化し，原子番号効果係数を算出して掛け れば，ZAF 法と全く同様の值が得られることとなる。しかし ながら，上記の補正計算が $\rho_{\mathrm{F}}$ の関数で与えられている以上, ZAF 法と同様に $F(0)$ で規格化すれば，その関数はX線発生 領域に対して全く無関保なるのとなってしない，X楾発生領 域以対する補正については改めて行わなけ狆ばならないという ことになる。

$\mathrm{ZAF}$ 法の立場で考吕るならば，X 線発生領域関寸る項は 当然，原子番号効果以含まれるべきものである，ZAF 法の場 合, 原子番号効果係数算出代用いられる関数は, イオン化断面 積と電子のエネルギー損失式，そして背面散乱因子 $R$ から構 成されている。これらには，それぞれいくつかの式が提唱され ているが，いずれる電子のェネルギーの関数で与兄られて利 りこれを深さ方向の mass thickness $\rho x$ の関数として取り圾 らためにはかなり複雑な計算を要する。事害, 実際のZAF 法 に用いられている原子番号効果係数算出の計算式もかなり簡略 化されて却り，電子のエネルギーには依存せず電子線の加速電 圧と各元素の最小励起電圧のみに俵存する関数として与党られ ている。

このよらなことから, 今回の補正計算では, Philibert のX 線発生関数学用いて算出したX 線発生強度の值を $F(0)$ で規格 化せずに使用し，さらに不十分な原子番号効果については， Duncumb, Reed らにより与えられているものを，それぞれ電 子線のエネルギーに全く依存しない，単に平均原子番号の違い のみを補正する係数として採用することとした。

\section{（2）薄膜に対する従来法と本法の比較}

上記のようにして求めた試料 B K対する結果をFig. 4 亿示 す.ZAF法による補正計算では，明らかに高加速電圧になる にしたがって定量值がずれていくことがわかる。しかし，上記 の補正計算により得られた定量值は，加速電王の变化に対して ほぼ同等な值を示している。委た，低加速電生領域における本 補正計算での定量值は，ZAF 法によるものに非常に近い值を 示している、これらのことから考えて, 本補正計算が分析領域

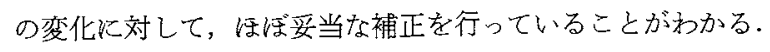
な技，加速電圧 $6 \mathrm{kV}, 8 \mathrm{kV}$ では，下地基板からの $\mathrm{FeK} \alpha$ 線が 観測されなかったため, 膜の密度としては高加速電任領域で求 めた密度の平均值を代入した。 


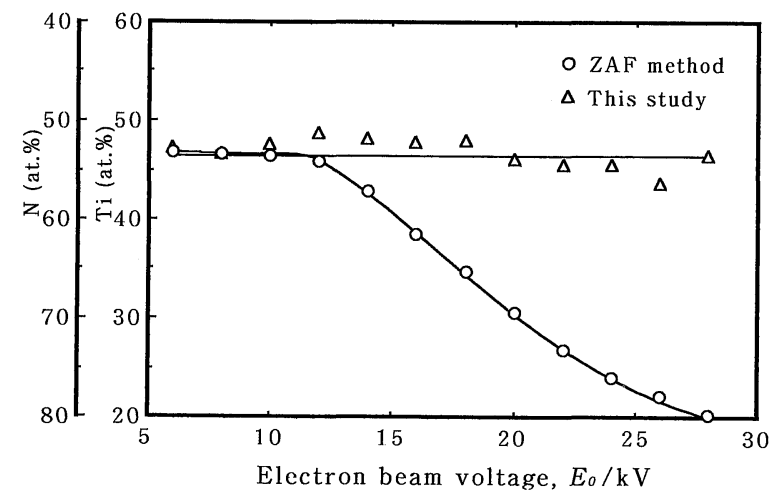

Fig. 4 A comparison of chemical composition of sample $B$ determined by the conventional ZAF method and by this method. Sample B consists of a film as thin as $0.54 \mu \mathrm{m}$, which allows the electron beam to penetrate into the substrate.

\section{（3）本法における誤差要因}

この補正計算では，X線発生領域の違いは，そのまま X 線 発生強度計算の項に含まれることとなるが，ZAF 法による補 正值との間には，ZAF 法が適用可能な範囲に揖いて余分に $F_{\mathrm{F}}(0) / F_{\mathrm{Std}}(0)$ が掛かることとなる. 今回の分析では, $F_{\mathrm{F}}(0) /$ $F_{\text {Std }}(0)$ の值は分析試料が $\mathrm{TiN} て ゙$ 標準試料が Ti の場合で 0.982 , 標準試料が VN の場合で0.996である.したがって, ZAF 法に括ける定量值が仮に真の濃度とするならば，今回の 補正計算で得られる定量值は，ずれの大きくなる $\mathrm{Ti}$ の定量値 の場合で約 $1.8 \%$ れるといらことになる. $F(0)$ の值は, 各試 料の平均原子番号と平均原子量の関数で与えられるため, 分析 試料と標準試料の間でこの 2 者の違いが大きくなればかなり の誤差が生じてしまらこととなる。しかし，今回の分析では， 各試料間の平均原子番号, 平均原子量に大きな差がないため, さほど大きな誤差にはならない，試料 A についてのこの方法 による定量補正計算では，ZAF 法との間で最大 $1.4 \%$ のずれと なった．各加速電圧に拈ける分析值のばらつきが，今回の分析 精度を表すとすれば，このずれはさほど大きなものとはいえな いと思われる.

むしろ注目すべき点は Fig. 3, 4 双方に見られる各加速電圧

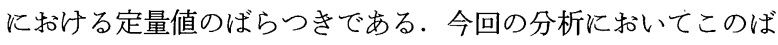
らつきを生じさす原因としては測定時に生じる測定誤差と補正 法による誤差の 2 つが考兄られる. Fig. 5 亿試料 A, B それぞ れから得られた各固有 $\mathrm{X}$ 線の標準試料に対する相対強度の加 速電圧による変化を示す. 試料 A の場合は Fig. 5 からも明ら かなように $\mathrm{NK} \alpha$ 線の相対強度の変化自体にばらつきが生じて いることがわかる。このばらつきは波形分離前の TiL1 線と $\mathrm{NK} \alpha$ 線の重嘼スペクトル強度の変化にも見られることから， 各測定時の測定䛊差の違いが影響しているものと思われる.た だ， $\mathrm{NK} \alpha$ 線強度に関することであるので，各測定に扣ける TiLl 線と NK $\alpha$ 線の分離精度の違いも $\mathrm{NK} \alpha$ 線強度に影響を与 えると考学れるが，このことは試料 A, B 双方でいえること であるが，そもそも今回の分離操作は重畳波形の面積がどのよ らな割合で重なっているのかを計算するものであるため，その 分離精度の違いが $\mathrm{NK} \alpha$ 線相対強度の変化に大きな影響を与え

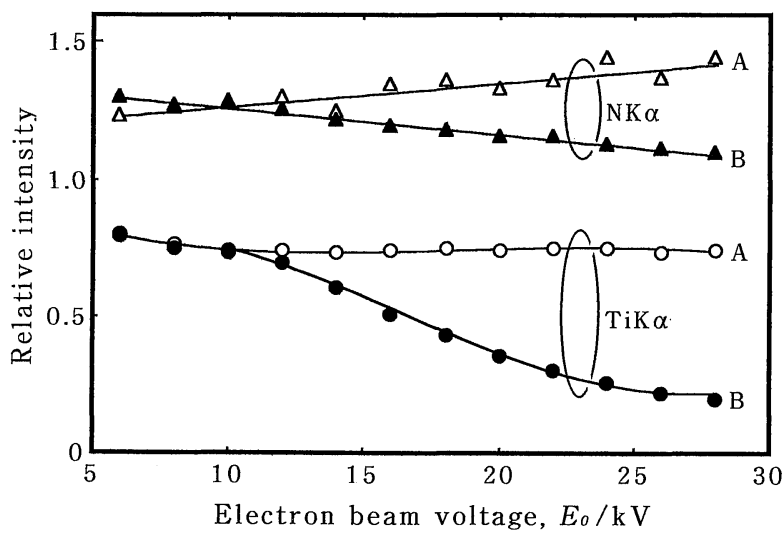

Fig. 5 The variation in relative intensity of $\mathrm{TiK} \alpha$ and $\mathrm{NK} \alpha$ from sample A and B to standard sample with electron beam voltage. Unfilled and filled marks indicate the values of samples $A$ and $B$, respectively; circular and triangular marks are corresponding to $\mathrm{TiK} \alpha$ and $\mathrm{NK} \alpha$, respectively.

る原因になるとは考兇くい。したがって，試料 A の場合の ばらつきは各測定に打ける測定誤差の違いの方が大きく影響を 与壳ている考えられる。しかしな゙ら，試料 Bについては これら以外にも定量值に影響を与える要因がいくつか考学られ る. 今回用いた補正計算はZAF 法の場合とは異なり, 試料の 膜厚と密度の積 (Mass thickness: $\rho t$ ) の誤差が定量值に大きな 影響を与えると思われる。すなわち，下地基板からの X 線強 度を用いて膜の $\rho t$ を算出しているため下地基板での $\mathrm{X}$ 線発生 関数の精度や試料の不均質などが直接影響するのである.この 場合，前者によるずれは Philibert の X 線発生関数を用いてい る以上精度が良いとはい党ないが, 補正計算を行う際にはこの 誤差がどの元素についても同じよらな形で現れるためさほど大 きな誤差とはならないと考㝋られる。後者の場合は, も乙 $\mathrm{FeK} \alpha$ 線の測定箇所と皮膜構成元素の固有 $\mathrm{X}$ 線の測定箇所で $\rho t$ が異なればかなりの誤差が生じることになる．試料 B では 測定箇所により $\mathrm{FeK} \alpha$ 線の強度が若干異なるといら現象が認 められて拉り，また，今回の分析ではコンタミネーションの影 響を避けるため測定箇所を変えて分析していることから，この 定量值のばらつきは試料の不均質に起因したもの之も考兄られ る.

\section{N. 結言}

EPMA に括ける定量補正法であるZAF 法を分析深さ，す なわち試料の膜厚を考慮したものに拡張することで薄膜試料に 対して適用可能なものとした。そして実際にその補正法を用い てチタン窒化物皮膜の定量分析を試みた。分析は膜厚が 12.55 $\mu \mathrm{m}$ の試料 A, 拉よび $0.54 \mu \mathrm{m}$ の試料 B の 2 種類の試料に対 して，それぞれ加速電圧を 6 から $28 \mathrm{kV}$ の範囲で行った.こ の加速電圧の範囲に执いて基板にまで電子線が到達していない と考学られる試料 A の分析では, 従来の補正法である ZAF 法 により得られた皮膜の定量值および本法による定量值の双方と もに加速電圧に対して変化しなかった。 しかし, $\mathrm{FeK} \alpha$ 線強度 の測定から，明らかに電子線が基板にまで到達していると考え 
られる試料 B の分析結果は，ZAF 法による定量値が加速電圧 に対して著しく变化するのに対して，本法による結果は加速電 压の変化に対してほぼ同程度の值を示した。 また，電子線が膜 を透過しないと考兄られる低加速電生領域に执いては，ZAF 法による補正計算值に近い值が得られた，以上これらの結果 は，本補正計算が深さ方向の分析領域の变化《対して医淁妥当 な補正を行っていることを示している。しかし，本補正計算で はPhilibert のX線発生関数を用いたため，ZAF 法との間に 常に若干のずれが生じることとなる。この違いはチタン堂化物 に対して今回分析に供した標準試料の組合せで約 $2 \%$ 前後のず れで留ることが見積すられた。このずれは，分析精度から考兄 ればさほぎ大きなずれではないと判断できる。

\section{文献}

(1) T. B. Massalski, J. L. Murray, L. H. Bennett and H. Baker: Binary Alloy Phase Diagrams Vol. 2, American Society for Metals, Metals Park, Ohio 44073, (1987), 1652.

(2) J. -E. Sundgren: Thin Solid Films, 128(1985), 21.

(3) 副島啓義: 電子線マイクロアナリシス, 日刊工業新聞 社, (1987), p. 360 .

(4) 可谷恒夫，加藤昭実：EPMA 飞よる薄膜の組成分析('82 日本電子 EPMA ニーザーズミーティング資料)。

(5) H. E. Bishop and D. M. Poole: J. Phys. D, 6 (1973), 1142.

(6) D. F. Kyser and K. Murata: IBM J. Res. Develop., $18(1974), 353$.

( 7 ) J. -E. Sundgren, B. -O. Johansson, S. -E. Karlsson and H. T. G. Hentzell: Thin Solid Films, 105(1983), 367.

（8）梶岡 秀, 清水達磨, 丸下清志, 尾辻康博, 川下安司: 広島県西部工業技術センタ一報告, $30(1987), 50$.

(9) 戸谷恒夫, 加藤昭実, 榎本祐嗣 : 真空, 25(1982), 75 .

(10) T. Shiraiwa, N. Fujino and J. Murayama: Trans. ISIJ, $10(1970), 406$.

（11）沖 猛雄 : 熱処理, 27(1987), 258. 